\title{
ГУМОРАЛЬНИЙ ІМУНІТЕТ У ДІТЕЙ ШКІЛЬНОГО ВІКУ ЗІ ПОЗАШПИТАЛЬНОЮ ПНЕВМОНІЕЮ
}

\author{
Бабік I. В., к. мед. н. \\ Украӥна, м. Львів, асистент кафедри педіатрії №1 \\ Львівського начіонального медичного університету ім. Данила Галицьького
}

DOI: https://doi.org/10.31435/rsglobal_ws/30082018/6060

\section{ARTICLE INFO}

Received: 18 July 2018

Accepted: 19 August 2018

Published: 30 August 2018

\section{KEYWORDS}

secretory immunoglobulin A, children,

school.

\begin{abstract}
Secretory immunoglobulin A (sIgA) is often characterized as a component of the immune systems "first-line of defense" against pathogenic microorganisms, viruses, and bacteria. A lower concentration of sIgA in saliva has been conceptualized as a risk factor for upper respiratory infection in children. Also, individual differences in sIgA levels in response to infection have been identified as potential risk factors. No gender differences in SIgA levels have been reported. sIgA in saliva is not directly related to serum levels of sIgA.
\end{abstract}

Citation: Бабік I. B. (2018) Humoralnyi Imunitet u Ditei Shkilnoho Viku zi Pozashpytalnoiu Pnevmoniieiu World Science. 8(36), Vol.2. doi: 10.31435/rsglobal_ws/30082018/6060

Copyright: (C) 2018 Бабік I. B. This is an open-access article distributed under the terms of the Creative Commons Attribution License (CC BY). The use, distribution or reproduction in other forums is permitted, provided the original author(s) or licensor are credited and that the original publication in this journal is cited, in accordance with accepted academic practice. No use, distribution or reproduction is permitted which does not comply with these terms.

Вступ. Секреторний імуноглобулін A (sIgA) є основним компонентом секретів: слини, поту, слізної рідини, слизових оболонок носа, кишечника й дихальних шляхів. Секреторний компонент IgA забезпечує їхню резистентність до дії протеїназ шлунково-кишкового тракту. У секретах організму slgA зв'язується 3 вірусами і бактеріями (вуглеводні компоненти бактеріальних клітин з'єднуються із секреторним компонентом молекули $\operatorname{sig} \mathrm{A})$, тим самим, запобігаючи їх адгезії до поверхні слизової оболонки [2, 4]. Секреторний $\operatorname{IgA} є$ продуктом кооперації двох типів клітин - епітеліальних і плазматичних. Найактивнішим стимулом для синтезу $\operatorname{sg}$ А в кишечнику є мікробні антигени. Ряд мікробів має здатність до інактивації $\operatorname{sg} A$, зокрема, деякі штами клебсієл, бактероїди. Секреторний $\operatorname{IgA} \epsilon$ блокатором адгезії патогенів, медіатором нейтралізації вірусів на поверхні епітелію слизових оболонок [3].

На становлення місцевого імунітету діє мікрофлора кишечника, під впливом якої в ранній неонатальний період відбувається формування імунної відповіді. За участю мікроорганізмів виділяються лізоцим і інші активні сполуки, які стимулюють імунну систему організму. Нормальна мікрофлора кишечника викликає антигенне подразнення слизової оболонки кишечника, потенціюючи включення механізмів системного й локального імунітету: підвищується синтез імуноглобуліну Е, пропердину, комплементу, лізоциму. Слиз, що містить секреторний $\operatorname{IgA}$, захищає слизову оболонку шлунково-кишкового тракту від деграгації макромолекул, фізичної й хімічної агресії, а також від атак мікробів, бактеріальних токсинів і паразитів. Секреторний $\operatorname{IgA}$, справляючи бактерицидну дію, виконує роль головного «очищувача» слизової оболонки шлунково-кишкового тракту [7].

Істотний вплив на лімфоїдну тканину (стимулюючи не тільки місцеву, а й системну відповідь) виконують пробіотики, які перебувають у просвіті шлунково-кишкового тракту. Біфідобактерії беруть участь у формуванні імунологічної реактивності, стимулюючи лімфоїдний апарат, синтез імуноглобулінів, сприяючи збільшенню рівня пропердину й комплементу. На тлі зниження кількості біфідобактерій підвищується проникність епітеліального бар'єру кишечника для макромолекул їжі та знижується рівень секреторного IgA. Біфідобактерії здатні секретувати речовини, які пригнічують ріст патогенних 
мікроорганізмів, створювати кисле середовище в кишечнику шляхом продукції ацетату й молочної кислоти [1].

Причинами порушень місцевого імунітету шлунково-кишкового тракту є бактеріальні та вірусні інфекції, прийом антибактеріальних препаратів, хронічні соматичні захворювання, нераціональне харчування, стреси. Вплив цих негативних факторів можливий як безпосередньо через імунну систему, так і внаслідок порушеного балансу мікрофлори кишечника [5].

При виконанні поставлених задач про механізм синтезу секреторних імуноглобулінів було встановлено, що IgA і секреторний компонент синтезуються в різних клітинах: IgA - y плазматичних клітинах власної пластинки слизової оболонки рота й інших порожнин організму, а секреторний компонент - в епітеліальних клітинах. Секреторний IgA має виражену антивірусні й антитоксичні властивості, бактерицидність, стимулює фагоцитоз, активує комплемент, відіграє вирішальну роль у реалізації резистентності до інфекції.

Один 3 важливих механізмів антибактеріального захисту порожнини рота полягає в запобіганні за допомогою IgA прилипания бактерій до поверхні клітин слизових оболонок. Таким чином, секреторні IgA захищають внутрішнє середовище організму від різних агентів, що попадають на слизові оболонки [6].

Таким чином, секреторний $\operatorname{IgA,~будучи~важливим~елементом~місцевого~імунітету,~}$ захищає слизові оболонки як від поселення на них патогенних мікроорганізмів, так i від проникнення останніх у внутрішнє середовище організму. Тим більше важливо наявність синергізму між IgA і механізмами неспецифічної захисту — комплементом, лізоцимом, фагоцитируючими клітинами i їх ферментами, що сприяє здійсненню антибактеріальної захисту, підвищуючи в цілому їі ефективність.

Результати дослідження. Проводилося дослідження вмісту секреторного імуноглобуліну А в слині у дітей із позашпитальною пневмонією віком 7-14 років та проводилися методи корекції його порушення.

За методикою представлене клінічне дослідження було одноцентровим, відкритим у якому взяли участь 80 дітей обидвох статей у віці 7-14 років із діагнозом позашпитальна пневмонія. Діагноз пневмонії встановлювався на основі рекомендацій Всесві́тньої організа́ції охоро́ни здоро́в'я, як захворювання нижніх відділів дихальних шляхів, що проявляється лихоманкою і/або задишкою iз наявністю вогнищевого інфільтрату на рентгенографії грудної клітки.

Всі діти, які були включені в дослідження, на стаціонарне лікування потрапляли на 2-4 день захворювання, у розпалі клінічної симптоматики позашпитальної пневмонії в гострий перебіг, загальний стан дітей під час госпіталізації можна було розцінювати, як середньої важкості.

Дослідження проводилося у дітей в групі спостереження під час захворювання на позашпитальну пневмонію на 1-й день нормалізації температури та на 30 день лікування. Діти були розподілені на дві групи - перша група (основна) 40 дітей, яким до стандартного лікування додатково призначались препарати зі вмістом цитруліну малату та симбіотичний

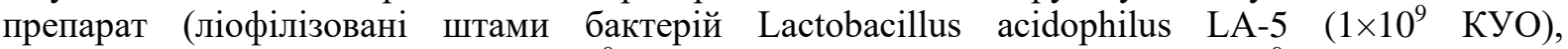

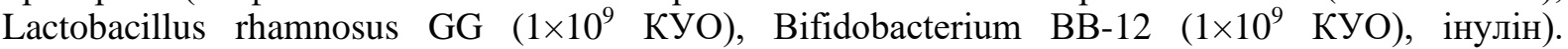
Препарати діти отримували впродовж 15 днів. Друга група (контрольна) 40 дітей - отримувала стандартне лікування.

Результати визначались за допомогою імуноферментного методу обстеження (див. у таблиці 1).

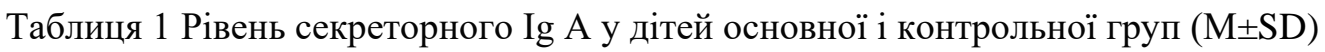

\begin{tabular}{|l|c|c|}
\hline Групи & sIg A, мг/л (на початку) & sIg A, мг/л (через 30 днів) \\
\hline Основна (40 дітей) & $95,9 \pm 1,07^{*}$ & $258,2 \pm 5,7^{*}$ \\
\hline Контрольна (40 дітей) & $92,3 \pm 1,01^{*}$ & $158,9 \pm 5,6^{*}$ \\
\hline
\end{tabular}

Примітка: * - достовірна різниця у групі до та після лікування $(\mathrm{p}<0,05)$

Отримані дані свідчать про те, що під впливом симбіотика та амінокислот у дітей основної групи вже на 30 добу спостерігались значно кращі результати гуморального імунітету. 


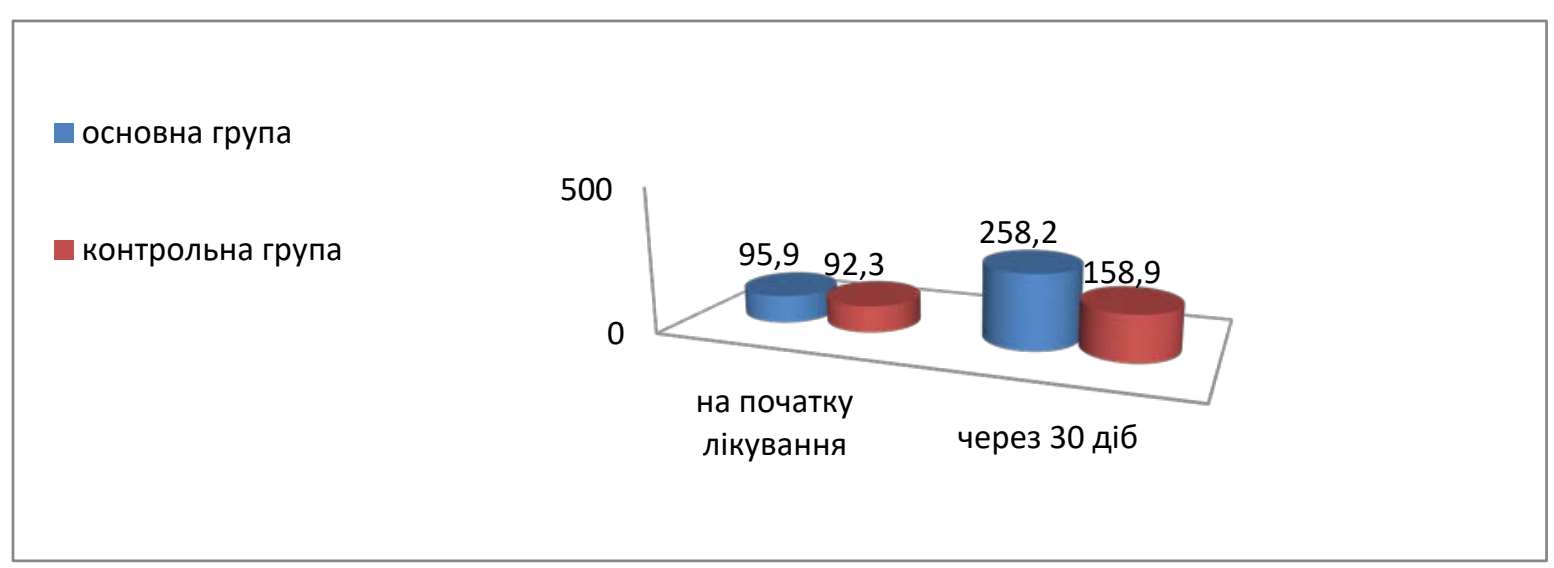

Рис. 1. Рівень сектреторного імуноглобуліну А у дітей із позашпитальною пневмонією.

Для більш наочного прикладу відображено показники імунологлобуліну А у гістограмі (Рис.1):

Висновки. Вміст імуноглобуліну А у слині дітей хворих на позашпитальну пневмонію знаходиться на дуже низькому рівні. Призначення препаратів із малат цитроліном та симбіотиком 3 профілактичною метою дітям із позашпитальною пневмонією у ранній реабілітаційний період сприяє зниженню частоти нових захворювань або рецидивам попереднього. Підвищує рівень місцевого гуморального імунітету, зокрема секреторного імуноглобуліну А у слині. Дані препарати можуть рекомендуватись у практику педіатрам та сімейним лікарям.

\section{ЛIТЕРАТУРА.}

1. Виха Г. В. Диагностика адаптивно-компенсаторных реакций организма, ориентированная на контроль эффективности профилактических мер и реабилитации / Г. В. Виха, В. А. Исаев // Материалы научно-практических конгрессов IV Всероссийского форума «Здоровье нации — основа процветания России». — Москва, 2008. - Т.3. - С. 97-101.

2. Виха Г. В. Иммуноглобулин А (sIgA) в доказательной лабораторной диагностике / Г. В. Виха, И. П. Папазов, А. И. Воложин // Нетрадиционные природные ресурсы, инновационные технологии и продукты. - 2005. - № 13. - С. 89-102.

3. Виха Г. В. Молекулярный маркер адаптации организма и диагностический набор для его измерения в секретах / Г. В. Виха // Молекулярная медицина и биобезопасность. - М., 2005. - С.46-49.

4. Виха Г. В. Молекулярный маркер адаптационной защиты организма и диагностический набор для его определения в секретах организма / Г. В. Виха // Нетрадиционные природные ресурсы, инновационные технологии и продукты. - 2003. - № 10. - С. 144-155.

5. Виха Г. В. Тенденции и перспективы развития лабораторной диагностики XXI века. / Г. В. Виха, В. А. Исаев //Материалы научно-практических конгрессов IV Всероссийского форума «Здоровье нации - основа процветания России». - Москва, 2009. - Т.5. - С.60-63.

6. Лапин А. А. Неинвазивный метод определения антиоксидантного статуса организма / А. А. Лапин, Г. В. Виха, В. Н. Зеленков // Нетрадиционные природные ресурсы, инновационные технологии и продукты. - 2011. - №19. - С. 9-20.

7. Секреторный иммуноглобулин А в контроле адаптивно-компенсаторных реакций организма человека / Г. В. Виха, О. А. Сердюк, Т. В. Выгодская, А. В. Фурсова // Медицинский Алфавит. Современная лаборатория. - 2011. - №4. - С. 24-26. 